\title{
Trade-offs and spatial variation of functional traits of tree species in a subtropical forest in southern Brazil
}

\author{
Francieli de Fátima Missio ${ }^{(1)}$, \\ Pedro Higuchi ${ }^{(1)}$, \\ Ana Carolina da Silva ${ }^{(1)}$, \\ Solon Jonas Longhi ${ }^{(2)}$, \\ Bruna Salami (1), \\ Angélica Dalla Rosa ${ }^{(1)}$, \\ Fernando Buzzi-Junior (1) \\ Tiago de Souza Ferreira (1), \\ Amanda Koche Marcon ${ }^{(1)}$, \\ Marco Antonio Bento ${ }^{(1)}$
}

\begin{abstract}
Plant functional traits have been recognized as important factors related to the ecological strategies of species in forest ecosystems. We examined the relationships between functional traits and both tree species performance and environmental conditions in a subtropical forest in Brazil. Over four years (2008-2012), we investigated how demographic rates were related to functional traits (wood density, leaf area and tree height) of 20 species sampled within 50 plots of $10 \times 20 \mathrm{~m}$, which had previously evaluated as to environmental conditions. Non-metric multidimensional scaling was used to order the species by their functional traits. The demographic rates were fit a posteriori to the ordination, with significant rates $(p<0.05)$ plotted as vectors. The relationships between environmental conditions and the community-weighted means (CWMs) of trait values were verified using redundancy analysis. CWM wood density was positively correlated with soil $\mathrm{pH}$. CWM leaf area and CWM maximum tree height were both negatively correlated with altitude and positively correlated with soil magnesium $(\mathrm{Mg})$ content. The taller species with lower wood density, which occupied the forest canopy, had a greater diameter increment and lower recruitment than did the shortest species with higher wood density. The shorter species with higher wood density, which occupied the understory, had greater recruitment and a greater increase in abundance than did the taller/lower-wood-density species. Our study (i) revealed changes in the forest related to the light environment, with an increase in the relative participation of shade-tolerant species with higher wood densities, and (ii) detected small-scale spatial variation in community traits as a response to variations in soil chemical properties and topography.
\end{abstract}

Keywords: Araucaria Forest, Atlantic Forest, Environmental Heterogeneity, Multivariate Analysis

well 2007), which result in different species performances according to the environmental conditions (Lebrija-Trejos et al. 2010). Thus, the fitness of different organisms in their environment reflects the adaptive values and life strategies of the species, and affects the demographic rates and spatial variation of traits in communities (Reich et al. 2003, Poorter et al. 2008, Chave et al. 2009). In general, species with forms and functions that maximize net carbon balance and growth in a given environment will typically succeed in that environ-
(1) Forestry Department, Agroveterinary Center, Santa Catarina State University, Av Luiz de Camões, 2090, Conta Dinheiro, 88.520-000, Lages, SC (Brazil); (2) Forestry Department, Santa Maria Federal University, 97105-900 Santa Maria, RS (Brazil)

@ Pedro Higuchi (higuchip@gmail.com)

Received: Dec 19, 2015 - Accepted: Apr 19, 2016

Citation: Missio FF, Higuchi P, Silva AC, Longhi SJ, Salami B, Dalla Rosa A, Buzzi-Junior F, Ferreira TS, Koche Marcon A, Bento MA (2016). Trade-offs and spatial variation of functional traits of tree species in a subtropical forest in southern Brazil. iForest 9: 855-859. - doi: 10.3832/ifor1960-009 [online 2016-07-07]

Communicated by: Andrea Cutini ment (Reich et al. 2003).

Many studies have demonstrated the existence of a growth-mortality trade-off among species in closed canopy tropical forests (Wright et al. 2003, 2010, Poorter \& Bongers 2006, Poorter et al. 2008), which has mainly been associated with the responses of different life strategies of species to the environmental heterogeneity of light (Poorter et al. 2006, Wright et al. 2010). For shaded forest understory species, the investment in wood density and long-lived, well-protected leaves represents an important strategy for mechanical resistance to stem damage and the avoidance of biomass loss, thereby increasing survivability (Poorter \& Bongers 2006). In contrast, gaps and earlier successional forest patches are dominated by light-demanding species that invest in short-lived and physiologically active leaves, which results in a rapid growth and thus an increased access to light (Poorter \& Bongers 2006, Poorter et al. 2008).

Differences in species performance may represent a product of ecological filtering that reflects the species' fitness to their existing environment. Therefore, linkages among community functional traits and environmental conditions are expected. 
These patterns have been observed at different spatial scales as a function of climatic variables, topography, altitude, soil and disturbances (Müller et al. 2007, Kyle \& Leishman 2009, Kooyman et al. 2010). Whereas acquisitive traits, such as rapid growth and soft wood density, are commonly found in environments providing greater resource availability (e.g., canopy gaps and nutrient-rich soils), conservative traits, such as slow growth and hard wood density, are usually observed in low-resource environments (e.g., shaded understories, low-fertility soils - Baker et al. 2003, Apaza-Quevedo et al. 2015). Thus, knowledge of these patterns contributes to the understanding of the breadth of tree species niches in forest ecosystems.

Studies that evaluate how variations in plant functional traits affect species performance and how functional traits are influenced by environmental conditions are important for understanding forest ecosystem ecology. In the present study, we aimed to investigate the relationships between functional traits and tree species performance, and between community traits and environmental gradients in a subtropical evergreen forest in Brazil. Our objective was to determine how the demographic rates of tree species are mediated by their functional traits and how community traits vary spatially in response to environmental heterogeneity. We tested the hypothesis that in the study forest, the ecological strategies of species differ under different light and edaphic environments, with species with acquisitive traits succeeding under high-resource conditions (e.g., canopies and nutrient-rich soils) and species with conservative traits thriving in low-resource environments (understorey and low-fertility sites).

\section{Materials and methods}

The present study was conducted in a fragment of subtropical evergreen forest, classified as Araucaria Forest, with an approximate area of 103.06 ha and an altitude ranging from 990 to $1000 \mathrm{~m}$ a.s.l. It is located at latitude $27^{\circ} 51^{\prime} 19.20^{\prime \prime} \mathrm{S}$ and longitude $50^{\circ} 10^{\prime} 33.39^{\prime \prime} \mathrm{W}$ in the municipality of Lages, Santa Catarina, Brazil. The mean precipitation and annual temperature for the region (1970-2010) are $1682.80 \mathrm{~mm}$ and $15.9^{\circ} \mathrm{C}$, respectively (Higuchi et al. 2012).

The 20 most abundant woody species, representing 69.9 and $83.1 \%$ of the community abundance and basal area, respectively, were sampled over 1 ha in 50 plots of $10 \times 20 \mathrm{~m}$. The environmental conditions of the plots (chemical and physical properties of the soil and topography) had been evaluated as part of the research conducted by Higuchi et al. (2012). The richest botanical families in the study area are Myrtaceae (22 species), Lauraceae (7) Aquifoliaceae (5), Asteraceae (5), Fabaceae (5) and Salicaceae (5 - Higuchi et al. 2012). For the sampled species, the functional traits (wood density, leaf area and maximum height) were determined. The demographic rates (recruitment, mortality, basal area gain, basal area loss, basal area increment of survival, net change and turnover) were recorded for four years (2008-2012) by Salami et al. (2014), based on Lieberman et al. (1985), Korning \& Balslev (1994), Sheil \& May (1996) and Oliveira-Filho et al. (2007) as follows (eqn. 1 to eqn. 8 ):

$$
\begin{aligned}
& \text { Mort }=\left[1-\left(\frac{N_{o}-m}{N_{o}}\right)^{\frac{1}{t}}\right] \cdot 100 \\
& \text { Recr }=\left[1-\left(1-\frac{r}{N_{t}}\right)^{\frac{1}{t}}\right] \cdot 100 \\
& \text { Loss }=\left[1-\left(\frac{A B_{o}-\left(A B_{m}+A B_{d}\right)}{A B_{o}}\right)^{\frac{1}{t}}\right] \cdot 100 \\
& \text { Gain }=\left[1-\left(1-\frac{A B_{r}+A B_{g}}{A B_{t}}\right)^{\frac{1}{t}}\right] \cdot 100 \\
& \text { Nchg }=\left[\left(\frac{N_{t}}{N_{o}}\right)^{\frac{1}{t}}-1\right] \cdot 100 \\
& \text { Abchg }=\left[\left(\frac{A B_{t}}{A B_{o}}\right)^{\frac{1}{t}}-1\right] \cdot 100 \\
& \text { Nturn }=\frac{\text { Mort }+ \text { Recr }}{2} \\
& \text { Abturn }=\frac{\text { Gain }+ \text { Loss }}{2}
\end{aligned}
$$

where Mort is the annual mortality rate, Recr is the annual recruitment rate, Loss is the annual basal area loss rate, Gain is the annual basal area gain rate, $t$ is the time interval between inventories, $N_{\mathrm{o}}$ is the initial number of trees, $N_{\mathrm{t}}$ is the final number of surviving trees after $t, m$ is the number of dead trees, $r$ is the number of recruited trees, $A B_{\mathrm{o}}$ is the initial basal area, $A B_{\mathrm{t}}$ is the final basal area after $t, A B_{\mathrm{m}}$ is the basal area of dead trees, $A B_{\mathrm{d}}$ is the basal area loss (diametric reduction and partial loss of stems), $A B_{\mathrm{r}}$ is the basal area of recruited trees, $A B_{\mathrm{g}}$ is the basal area gain (tree growth), Nchg is the tree annual net change, Abchg is the basal area net change, Nturn is the tree turnover, and Abturn is the basal area turnover.

The determination of wood density data and leaf area was performed according to Pérez-Harguindeguy et al. (2013). A total of 10 individuals per species were sampled (overall 200 samples) using an increment borer with a diameter of $5.15 \mathrm{~mm}$. In the laboratory, these samples remained immersed in water to obtain a constant wet weight. The volumes were obtained by the water-displacement method (Archimedes' principle). The samples were then dried in an oven for 72 hours until stabilization of the dry mass, and the dry weight was determined using an analytical scale. The wood density values were determined as the ratio between the dry weight and the volume $\left(\mathrm{g} \mathrm{cm}^{-3}\right)$. The leaf area, including petioles and rachis for compound leaves, was obtained by sampling 20 leaves from each individual of each tree species (10 individuals per species). Healthy leaves, without visible damage by herbivores, were collected. The leaf samples were stored in sealed plastic bags to prevent water loss during transport to the laboratory, where the leaves were photographed and the leaf area was determined using Image ${ }^{\circledast}$ software (Rasband 2007). The maximum heights of the tree species was assessed through field observations and literature review (Lorenzi 1988, 2000).

Non-metric multidimensional scaling (NMDS) was used to ordinate the species according to their functional traits. The demographic rates were fit a posteriori to the NMDS ordination, with the significant rates $(p<0.05)$ plotted as vectors. For assessing the community functional responses to the environmental gradient, the community-weight matrix and redundancy analysis (CWM-RDA) method was performed (Kleyer et al. 2012). For this method, the community-weighted means of trait values (CWMs) were determined for each plot. Then, a multivariate forward selection by permutation of residuals $(n=999)$, in which the data were centered and scaled, was performed to identify significant environmental variables in the CWM. Subsequently, the relationships among the environmental variables and the CWM were verified using a redundancy analysis (RDA). All of the analyses were performed using the $\mathrm{R}$ statistical programming environment (R Development Core Team 2014) with the "vegan" (Oksanen et al. 2013) and "FD" (Laliberté \& Legendre 2010, Laliberté \& Shipley 2011) packages.

\section{Results}

The mean values of maximum height, leaf size and wood density were $16.55 \mathrm{~m}, 33.86$ $\mathrm{cm}^{2}$ and $0.44 \mathrm{~g} \mathrm{~cm}^{-3}$, respectively. The NMDS ordination indicated the existence of relationships between species functional traits and their demographic rates ( $p$ < 0.01 - Fig. 1). Whereas Axis 1 of the NMDS ordination reflected a gradient associated with leaf area, with small-leaved species on the left and larger-leaved species on the right, Axis 2 represented a gradient related to wood density and maximum height. The species that had greater recruitment and greater basal area turnover were predominantly those with lower maximum heights $(<14 \mathrm{~m})$ and higher wood densities (> 0.60 $\mathrm{g} \mathrm{cm}^{-3}$ ), which were located predominantly towards the top of the ordination plot. The species with the greatest increases in the diameter increment had the highest maximum heights ( $>19 \mathrm{~m}$ ), which occupied the upper forest canopy and were located towards the bottom of the ordination. No relationships were observed between functional traits and mortality rate, basal area loss, basal area gain or tree turnover. The size of the leaves also did not influence the demographic rates of the species.

The forward selection identified three significant variables (elevation, soil $\mathrm{pH}$ and soil $\mathrm{Mg}-p<0.05)$ that explained $17.72 \%$ of 
Fig. 1 - Ordination produced by non-metric multidimensional scaling (NMDS) of tree species in a subtropical Araucaria Forest in southern Brazil as a function of their functional traits, with significant demographic rates $(p<0.05)$ plotted as vectors. (wd): wood density; (la): leaf area; (hmax): maximum height of trees: (Abturn): basal area turnover; (Nchg): tree annual net change; (recr): annual recruitment rate; (incr): survival diametric increment; (Alledu): Allophylus edulis; (Araang): Araucaria angustifolia; (Bantom): Banara tomentosa; (Calcon): Calyptranthes concinna; (Casdec): Casearia decandra; (Casobl): Casearia obliqua; (Cupver): Cupania vernalis; (Dastom): Dasyphyllum tomentosum; (Durves): Duranta vestita; (Jacpub): Jacaranda puberula; (Lamter): Lamanonia ternata; (Litbra): Lithraea brasiliensis; (Matela): Matayba elaeagnoides; (Myrgui): Myrcia guianensis; (Myrumb): Myrsine umbellata; (Ocopul): Ocotea pulchella; (Podlam): Podocarpus lambertii; (Sapgla): Sapium glandulosum; (Zankle): Zanthoxylum kleinii; (Zanrho): Zanthoxylum rhoifolium.

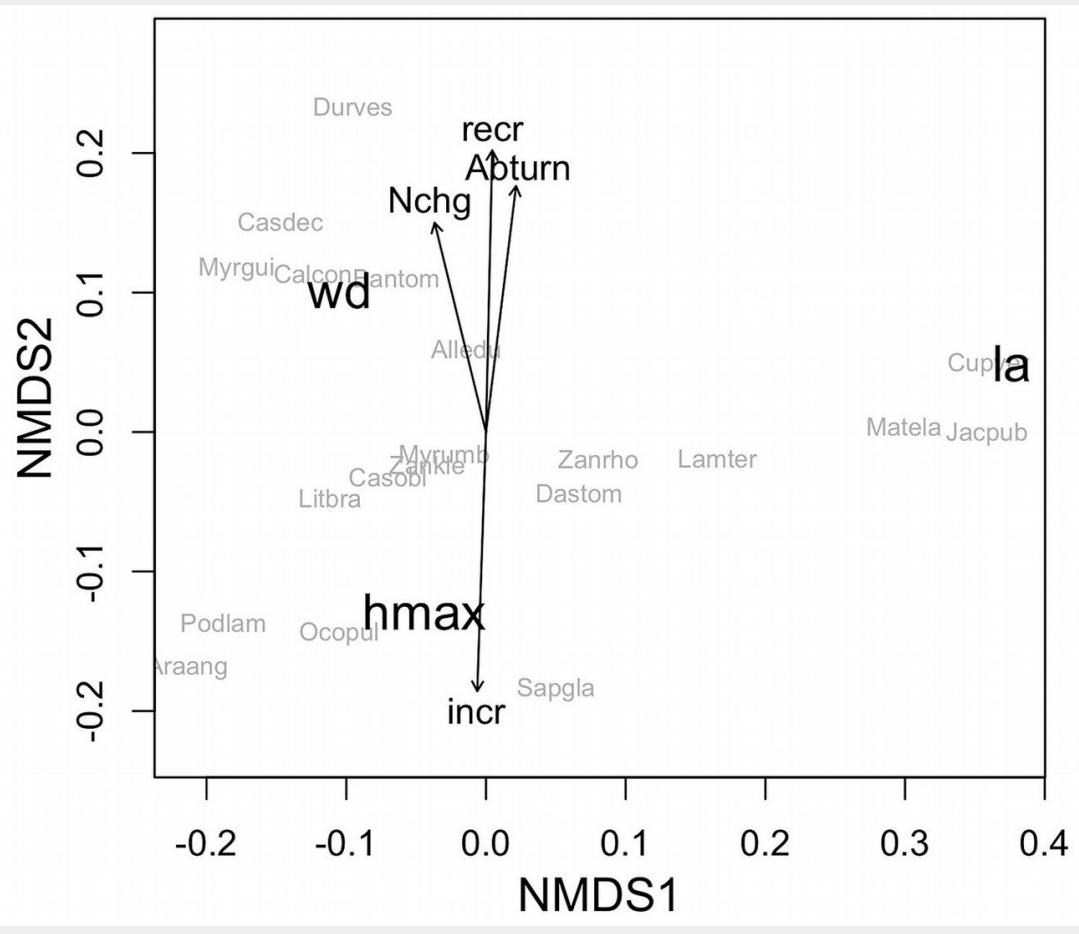

Tab. 1 - Environmental gradients and responses of the community traits of tree species represented by the correlation of each envi ronmental variable with the first two axes of the redundancy analysis (RDA) for a subtropical Araucaria Forest in southern Brazil. The values presented between parentheses after the axis names indicate the percentages of explained variation associated with each axis.

\begin{tabular}{|c|c|c|c|c|}
\hline Redundancy Analysis & $\begin{array}{l}\text { Statistics / } \\
\text { Axis (var. explained) }\end{array}$ & $\mathrm{pH}$ & $\begin{array}{c}\mathrm{Mg} \\
(\mathrm{cmol} \mathrm{dm})\end{array}$ & $\begin{array}{l}\text { Elevation } \\
(\mathrm{m})\end{array}$ \\
\hline \multirow{3}{*}{$\begin{array}{l}\text { Significant environmental gradient } \\
(p<0.05)\end{array}$} & Minimum & 3.8 & 0.1 & 900.7 \\
\hline & Mean & 4.8 & 1.9 & 1000.5 \\
\hline & Maximum & 6.3 & 4.5 & 1113.4 \\
\hline \multirow{2}{*}{$\begin{array}{l}\text { Response of community traits to gradients } \\
\text { (Total variation explained }=17.72 \% \text { ) }\end{array}$} & Axis 1 (73.15\%) & 0.31 & 0.66 & -0.57 \\
\hline & Axis $2(24.53 \%)$ & 0.95 & 0.47 & -0.38 \\
\hline
\end{tabular}

Fig. 2 - Ordination obtained by the Redundancy Analysis (RDA) of community traits as a function of environmental gradients in a subtropical Araucaria Forest in southern Brazil. (elev): elevation; (wd): wood density; (ph): soil pH; (Mg): soil Mg; (la): leaf area; (hmax): maximum height of trees.

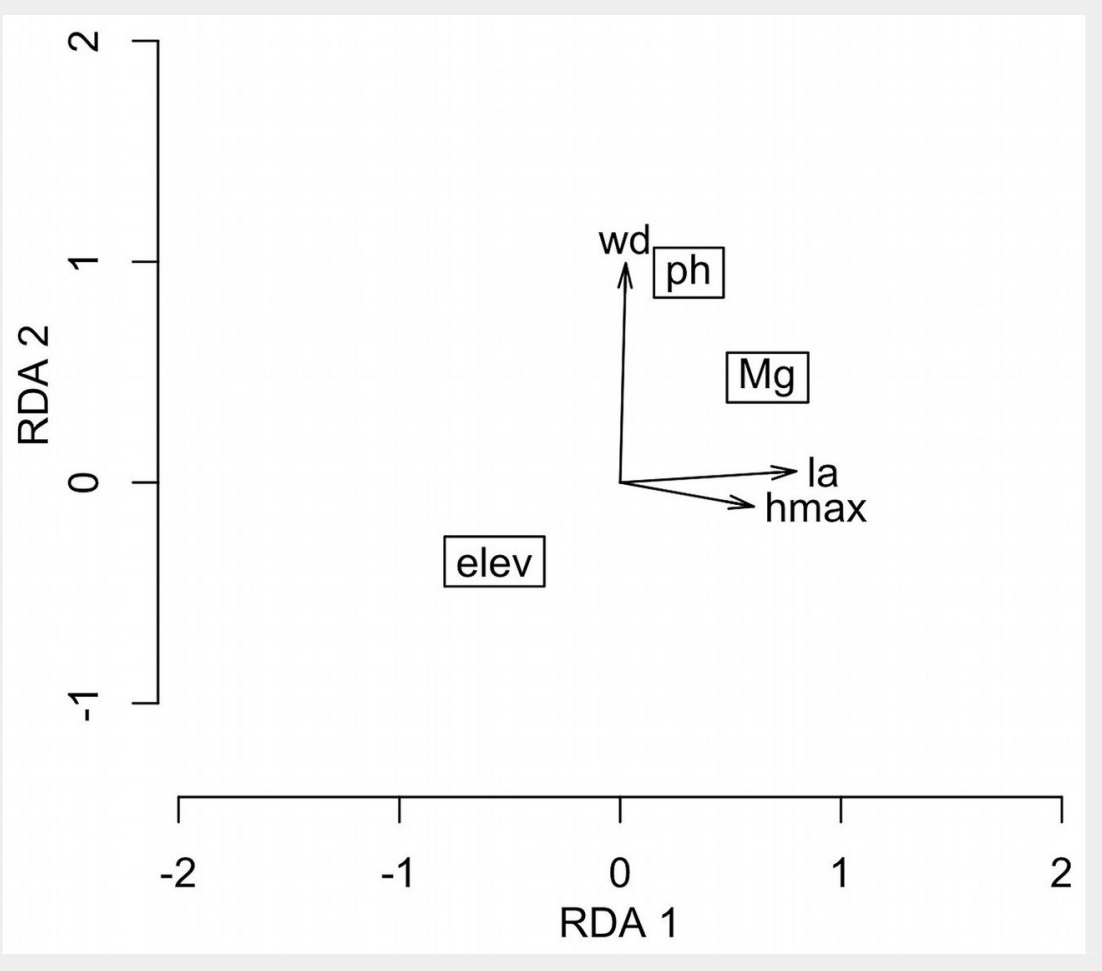


the variation in the community functional traits in the RDA (Tab. 1), with the first and second axis accounting for $73.15 \%$ and $24.53 \%$ of this total, respectively.

According to the RDA (Fig. 2), the sites with a higher wood density were associated with higher values of soil $\mathrm{pH}$, and the plots with smaller leaves and shorter species were associated with lower values of soil Mg content and higher elevations. In general, the results (Fig. 1 and Fig. 2) demonstrate that the species with higher wood densities, higher rates of recruitment, and increases in both the numbers of individuals and basal area turnover rates occurred predominantly in sites with the highest $\mathrm{pH}$ values, whereas the larger species with the highest diameter increments occurred mainly in the lower elevation sites with soils with the highest Mg contents.

\section{Discussion}

Considering the relationships between demographic rates and functional traits in tree species, a clear trade-off was evident between the allocation of resources for growth and the allocation for wood density. The species of larger size and lower wood density, which occupied the canopy of the forest, exhibited the highest diameter increments but lower recruitment, whereas the species of higher wood density and lower stature, which occurred in the understory, exhibited higher recruitment, greater increases in abundance and smaller diameter increments. This trade-off has been frequently cited for closed canopy forests (Wright et al. 2003, 2010, Poorter et al. 2008), and it is a consequence of the classical model of forest dynamics (Denslow 1987, Swaine \& Whitmore 1988), in which the dynamics are determined by the divergent life strategies of species under different light environments. Whereas light-demanding, pioneer species, which colonize gaps and grow rapidly, represent one extreme of this gradient, shade-tolerant species represent the other extreme, growing slowly under the canopy and presenting elevated survival rates (Wright et al. 2010).

In a more stable, low-resource environment, such as the forest understory, the investment in wood density represents a strategy for mechanical resistance to stem damage, thereby increasing survivability, whereas the greater diameter increment of large trees can be explained by greater access to light (Poorter et al. 2008). Furthermore, as noted by Chave et al. (2009), the negative relationship between wood density and growth rate is expected because a higher wood density is the result of a greater investment in a smaller volume of wood per unit of biomass, and dense wood may result in a lower proportion of conduit, thus affecting transpiration, photosynthesis and growth.

Although some authors have demonstrated a strong association between mortality and the life strategies of species
(Wright et al. 2003, 2010, Poorter \& Bongers 2006, Poorter et al. 2008), this was not the case in the present study. Our result might reflect the successional stage of the forest, where despite their lower recruitment, the large-sized species with lower wood densities and greater diametric increments had not yet reached the senescence phase.

Considering the spatial variation of community traits, the results indicate the influence of environmental conditions on these traits, which suggests the existence of ecological filters (Lebrija-Trejos et al. 2010) that are crucial for the occurrence of functionally similar species, most likely reflecting the adaptation of the species across environmental gradients (Reich et al. 2003). The species with higher maximum heights and larger leaves were dominant in the lower-elevation plots with higher values of soil Mg content, whereas the species with higher wood densities were predominant in the more basic soils. These results indicate the existence of small-scale ( 1 ha) spatial variation of functional traits and life strategies in the community, which are promoted by the heterogeneity of soil chemical properties and topography. The different life strategies observed for different species are suggested to be an important mechanism of ecological niche partitioning, which may explain the coexistence of species over short spatial scales (Kitajima \& Poorter 2008).

As low soil pH is an important factor limiting nutrient availability to plants, the pattern of higher community wood density in more basic soils observed in the present study was unexpected because a greater nutrient supply generally favors fast-growing species of lower wood density (Baker et al. 2003). However, the pattern observed here indicates that wood density may be also strongly affected by other ecological factors, such as disturbance history, that can influence the forest light environment and consequently, the spatial distribution of pioneer species, which usually have lower wood densities (Ter Steege \& Hammond 2001, Baker et al. 2003, 2004). Thus, in the present study the existence of lower wood density at sites with more acid soils could can be interpreted as the result of the occurrence of recent disturbances in this forest sector.

Despite the lack of relationship between leaf size and demographic rates, this functional trait was negatively correlated with terrain elevation and positively correlated with soil Mg content. Small leaves can increase the boundary-layer conductance (Gutschick 1999), allowing better control of water loss (Domingo et al. 1996). Thus, a small leaf size is usually recognized as a key adaptation for a greater water stress (Kessler et al. 2007), typically in areas with high incidence of solar radiation and wind, such as the upper positions of topographic gradients (Cornelissen et al. 2003). Similarly, as demonstrated by Fyllas et al. (2009), leaf functional traits are also influenced by edaphic gradients, with species with greater leaf masses per area succeeding in highfertility sites (Fyllas et al. 2009).

\section{Conclusions}

We conclude that a trade-off between the investment in growth and the investment in wood density led to an increase in the relative proportion of shade-tolerant species with higher wood densities in these forest fragments, thereby suggesting the predominance of stable, low-light environments. Furthermore, small-scale spatial variation in the community traits was observed as a response to the variations in soil chemical properties and topography.

\section{Acknowledgements}

The authors thank the Brazilian National Council for Scientific and Technological Development (CNPq) for the productivity research grant awarded to the second and third author, and Santa Catarina State University (UDESC) for the scholarship awarded to the first author.

\section{References}

Ackerly DD, Cornwell WK (2007). A trait-based approach to community assembly: partitioning of species trait values into within- and amongcommunity components. Ecology Letters 10 (2): 135-145. - doi: 10.1111/j.1461-0248.2006.0100 6.x

Apaza-Quevedo A, Lippok D, Hensen I, Schleuning $M$, Both S (2015). Elevation, topography and edge effects drive functional composition of woody plant species in Tropical Montane Forests. Biotropica 47: 449-458. - doi: 10.1111/btp. 12232

Baker TR, Swaine MD, Burslem DF (2003). Variation in tropical forest growth rates: combined effects of functional group composition and resource availability. Perspectives in Plant Ecology, Evolution and Systematics 6 (1): 21-36. doi: 10.1078/1433-8319-00040

Baker TR, Phillips OL, Malhi Y, Almeida S, Arroyo L, Di Fiore A, Erwin T, Killen TJ, Laurance SG, Laurance WF, Lewis SL, Lloyd J, Monteagudo A, Neill DA, Patiño S, Pitman NCA, Silva JNM, Martínez RV (2004). Variation in wood density determines spatial patterns in Amazonian forest biomass. Global Change Biology 10 (5): 545562. - doi: 10.1111/j.1365-2486.2004.00751.x

Cornelissen JHC, Lavorel S, Garnier E, Díaz S, Buchmann N, Gurvich DE, Reich PB, Ter Steege H, Morgan HD, Van Der Heijden MGA, Pausas JG, Poorter H (2003). Handbook of protocols for standardised and easy measurement of plant functional traits worldwide. Australian Journal of Botany 51 (4): 335-380. - doi: 10.1071/ BT02124

Chave J, Coomes DA, Jansen S, Lewis SL, Swenson NG, Zanne AE (2009). Towards a worldwide wood economics spectrum. Ecology Letters 12 (4): 351-366. - doi: 10.1111/j.1461-0248.2009.0128 5.x

Denslow JS (1987). Tropical rainforest gaps and tree species diversity. Annual Review of Ecology and Systematics 18 (1): 431-451. - doi: 10.1146/annurev.es.18.110187.002243 
Domingo F, Van Gardingen PR, Brenner AJ (1996). Leaf boundary layer conductance of two native species in southeast Spain. Agricultural and Forest Meteorology 81 (3): 179-199. doi: 10.1016/0168-1923(95)02326-7

Fyllas NM, Patiño $S$, Baker TR, Nardoto GB, Martinelli LA, Quesada CA, Paiva R, Schwarz M, Horna V, Mercado LM, Santos A, Arroyo L, Jiménez EM, Luizão FJ, Neill DA, Silva N, Prieto A, Rudas A, Silviera M, Vieira ICG, Lopez-Gonzalez G, Malhi Y, Phillips OL, Lloyd J (2009). Basinwide variations in foliar properties of Amazonian forest: phylogeny, soils and climate. Biogeosciences 6 (11): 2677-2708. - doi: 10.5194/bg6-2677-2009

Gutschick VP (1999). Biotic and abiotic consequences of differences in leaf structure. New phytologist 143 (1): 3-18. - doi: 10.1046/j.1469-81 37.1999.00423.x

Higuchi P, Silva AC, Ferreira TS, Souza ST, Gomes JP, Silva KM, Santos KF, Linke C, Paulino OS (2012). Influência de variáveis ambientais sobre o padrão estrutural e florístico do componente arbóreo, em um fragmento de Floresta Ombrófila Mista Montana em Lages, SC [Influence of environmental variables on the tree community structure and floristic patterns in a montane araucaria forest fragment in Lages, Santa Catarina State]. Ciência Florestal 22 (1): 79-90. [in Portuguese] - doi: 10.5902/198050985081

Kessler M, Siorak $Y$, Wunderlich $M$, Wegner $C$ (2007). Patterns of morphological leaf traits among pteridophytes along humidity and temperature gradients in the Bolivian Andes. Functional Plant Biology 34 (11): 963-971. - doi: 10.1071/FP07087

Kleyer M, Dray S, Bello F, Leps J, Pakeman RJ, Strauss B, Thuiller W, Lavorel S (2012). Assessing species and community functional responses to environmental gradients: which multivariate methods? Journal of Vegetation Science 23 (5): 805-821. - doi: 10.1111/j.1654-1103. 2012.01402.x

Kitajima K, Poorter L (2008). Functional basis for resource niche partitioning by tropical trees. In: "Tropical forest community ecology" (Carson WP, Schnitzer SA eds). Blackwell, Oxford, UK, pp. 160-181. [online] URL: http://www.research gate.net/publication/40095332

Kooyman R, Cornwell W, Westoby M (2010). Plant functional traits in Australian subtropical rain forest: partitioning within-community from cross-landscape variation. Journal of Ecology 98(3): 517-525. - doi: 10.1111/j.1365-2745.2010.016 $42 . x$

Korning J, Balslev H (1994). Growth and mortality of trees in Amazonian tropical rain forest in Ecuador. Journal of Vegetation Science 5 (1): 77-86. - doi: 10.2307/3235641

Kraft NJB, Valencia R, Ackerly DD (2008). Functional traits and niche-based tree community assembly in an Amazonian forest. Science 322 (5901): 580-582. - doi: 10.1126/science. 1160662

Kyle G, Leishman MR (2009). Plant functional trait variation in relation to riparian geomorphology: the importance of disturbance. Austral Ecology 34 (7): 793-804. - doi: 10.1111/j.14429993.2009.01988.x

Laliberté E, Legendre PA (2010). distance-based framework for measuring functional diversity from multiple traits. Ecology 91 (1): 299-305. doi: 10.1890/08-2244.1

Laliberté E, Shipley B (2011). FD: measuring functional diversity from multiple traits, and other tools for functional ecology. R package version 1:0-11.2011, web site. [online] URL: http://cran.rproject.org/web/packages/FD/index.html

Lebrija-Trejos E, Pérez-García EA, Meave JA, Bongers $F$, Poorter $L$ (2010). Functional traits and environmental filtering drive community assembly in a species-rich tropical system. Ecology 91 (2): 386-398. - doi: 10.1890/08-1449.1

Lieberman D, Lieberman M, Peralta R, Hartshorn GS (1985). Mortality patterns and stand turnover rates in a wet tropical forest in Costa Rica. Journal of Ecology 73 (3): 915-924. - doi: 10.2307 /2260157

Lorenzi H (1988). Árvores Brasileiras: manual de identificação e cultivo de plantas arbóreas nativas do Brasil [Brazilian trees: manual of identification and cultivation of native tree species from Brazil]. Instituto Plantarum, Nova Odessa, Brazil, pp. 352. [in Portuguese]

Lorenzi H (2000). Árvores Brasileiras: manual de identificação e cultivo de plantas arbóreas nativas do Brasil [Brazilian trees: manual of identification and cultivation of native tree species from Brazil]. Instituto Plantarum, Nova Odessa, Brazil, pp. 339. [in Portuguese]

Müller SC, Overbeck GE, Pfadenhauer J, Pillar VD (2007). Plant functional types of woody species related to fire disturbance in forest-grassland ecotones. Plant Ecology 189 (1): 1-14. - doi: 10.1007/s11258-006-9162-z

Oksanen J, Blanchet FG, Kindt R, Legendre $P$, Minchin PR, Hara RB, Simpson GL, Solymos P, Stevens MHH, Wagner H (2013). Vegan: community ecology package. $\mathrm{R}$ package version 2:0-10, web site. [online] URL: http://CRAN.Rproject.org/package=vegan

Oliveira AA, Vicentini A, Chave J, Castanho CT, Davies SJ, Martini AMZ, Lima RAF, Ribeiro RR, Iribar A, Souza VC (2014). Habitat specialization and phylogenetic structure of tree species in a coastal Brazilian white-sand forest. Journal of Plant Ecology 7 (2): 134-144. - doi: 10.1093/jpe/rt to73

Oliveira-Filho AT, Carvalho WAC, Machado ELM, Higuchi P, Appolinário V, Castro GC, Silva AC, Santos RM, Borges LF, Correa BS, Bueno JMA (2007). Din'mica da comunidade e de populações arbóreas de borda e interior de um remanescente florestal na Serra da Mantiqueira, Minas Gerais, em um intervalo de cinco anos (1999-2004) [Tree population and community dynamics in the edge and interior sectors of a forest remnant in the Mantiqueira Range, SE Brazil, over a five-year interval (1999-2004)]. Revista Brasileira de Bot'nica 30 (1): 149-161.

Pérez-Harguindeguy N, Díaz S, Garnier E, Lavorel $\mathrm{S}$, Poorter H, Jaureguiberry P, Bret-Harte MS, Cornwell WK, Craine JM, Gurvich DE, Urcelay C, Veneklaas EJ, Reich PB, Poorter L, Wright IJ, Ray P, Enrico L, Pausas JG, De Vos AC, Buchmann N, Funes G, Quétier F, Hodgson JG, Thompson K, Morgan HD, Ter Steege H, Van der Heijden MGA, Sack L, Blonder B, Poschlod $\mathrm{P}$, Vaieretti MV, Conti G, Staver AC, Aquino S, Cornelissen JHC (2013). New handbook for standardised measurement of plant functional traits worldwide. Australian Journal of Botany 61 (3): 167-234. - doi: 10.1071/BT12225
Poorter L, Bongers F (2006). Leaf traits are good predictors of plant performance across 53 rain forest species. Ecology 87 (7): 1733-1743. - doi: 10.1890/0012-9658(2006)87[1733:LTAGPO]2.0.C $\mathrm{O} ; 2$

Poorter L, Bongers L, Bongers F (2006). Architecture of 54 moist-forest tree species: traits, trade-offs, and functional groups. Ecology 87 (5): 1289-1301. - doi: 10.1890/0012-9658(2006)87 [1289:AOMTST]2.0.CO;2

Poorter L, Wright SJ, Paz H, Ackerly DD, Condit R, Ibarra-Manríquez G, Harms KE, Licona JC, Martínez-Ramos M, Mazer SJ, Muller-Landau HC, Peña-Claros M, Webb CO, Wright IJ (2008). Are functional traits good predictors of demographic rates? Evidence from five neotropical forests. Ecology 89 (7): 1908-1920. - doi: 10.1890 107-0207.1

R Development Core Team (2014). R: A language and environment for statistical computing. $\mathrm{R}$ Foundation for Statistical Computing, Vienna, Austria, Web site. [online] URL: http://CRAN.Rproject.org/

Rasband WS (2007). ImajeJ, version 1.42q. National Institute of Health, Bethesda, MD, USA, web site. [online] URL: http://imagej.nih. gov/ij/

Reich PB, Wright IJ, Cavender-Bares J, Craine JM, Oleksyn J, Westoby M, Walters MB (2003). The evolution of plant functional variation: traits, spectra, and strategies. International Journal of Plant Sciences 164 (S3): S143-S164. - doi: 10.1086 1374368

Salami B, Higuchi P, Silva AC, Ferreira TS, Marcon AK, Buzzi Junior F, Bento MA (2014). Influência de variáveis ambientais na din'mica do componente arbóreo em um fragmento de Floresta Ombrófila Mista em Lages, SC [The influence of environmental variables on tree species component dynamics in a montane Araucaria forest fragment in Lages, SC]. Scientia Forestalis 42 (102): 197-207. [in Portuguese] [online] URL: http://www.sifloresta.ufv.br/handle/123456789/ 15291

Sheil D, May RM (1996). Mortality and recruitment rate evaluations in heterogeneous tropical forests. Journal of Ecology 84 (1): 91-100. doi: $10.2307 / 2261703$

Swaine MD, Whitmore TC (1988). On the definition of ecological species groups in tropical rain forests. Vegetatio 75 (1-2): 81-86. - doi: 10.1007/ BFoo044629

Ter Steege H, Hammond DS (2001). Character convergence, diversity, and disturbance in tropical rain forest in Guyana. Ecology 82 (11): 31973212. - doi: 10.1890/0012-9658(2001)082[3197:C CDADI]2.0.CO;2

Wright SJ, Muller-Landau HC, Condit R, Hubbell SP (2003). Gap-dependent recruitment, realized vital rates, and size distributions of tropical trees. Ecology 84 (12): 3174-3185. - doi: 10.1890/ 02-0038

Wright SJ, Kitajima K, Kraft NJB, Reich PB, Wright IJ, Bunker DE, Condit R, Dalling JW, Davies SJ, Díaz S, Engelbrecht BMJ, Harms KE, Hubbell SP, Marks CO, Ruiz-Jaen MC, Salvador $C M$, Zanne AE (2010). Functional traits and the growth-mortality trade-off in tropical trees. Ecology 91 (12): 3664-3674. - doi: 10.1890/092335.1 